\title{
Zmiana preferencji wyborczych w Szwecji w wyniku kryzysu migracyjnego
}

\section{Changes within Voting Preferences in Sweden as a Result of the Migration Crisis}

\section{- Abstrakt •}

Kryzys migracyjny w sposób istotny wpłynął na sytuację wewnętrzną w Szwecji. Ze względu na intensywny napływ obcokrajowców i masowe wręcz składanie przez migrujących wniosków azylowych właśnie w tym państwie temat migracji stał się istotnym elementem dyskusji politycznej. Rodzi się zatem pytanie, czy intensyfikacja ruchów migracyjnych przyniesie widoczne zmiany w Szwecji - zwłaszcza w wymiarze politycznym oraz społecznym w obrębie poziomu dotychczasowej otwartości i tolerancji Szwedów. Celem artykułu jest weryfikacja hipotezy zakładającej, że zachodzi związek pomiędzy kryzysem migracyjnym, radykalizacją społeczeństwa szwedzkiego i wzrostem poparcia dla partii Szwedzkich Demokratów, jedynej w Szwecji partii o wyraźnym zabarwieniu antyimigracyjnym.

Słowa kluczowe: kryzys migracyjny; Szwecja; preferencje wyborcze

\section{- Abstract •}

The migration crisis influenced the internal situation in Sweden to a great extent. Owing to an intensive migrant inflow and a massive submission of asylum applications, the topic of immigration became an integral part of the political discourse. Therefore, a question should be asked, whether intensified migration will cause any visible changes in Sweden, especially in the field of politics and social attitudes towards foreigners. Sweden, until now, has been perceived as a tolerant and open state and society. The aim of the article is to test the hypothesis assuming that there is a correlation between the migration crisis, the radicalisation of the Swedish society and the growing support for the Sweden Democrats, the only anti-immigration political party in Sweden.

Keywords: migration crisis; Sweden; voting preferences

Kryzys migracyjny jest zjawiskiem wpływającym na wiele aspektów związanych z funkcjonowaniem państwa, a także na same społeczeństwa państw europejskich. Szwecja jest jednym z państw docelowych dla migrujących i obok Niemiec przyjmowała w szczytowym okresie kryzysu migracyjnego największe liczby 
uchodźców. W 2015 r. do Niemiec wpłynęło 442 tys. wniosków azylowych, a do Szwecji blisko 163 tys. (Eurostat, 2015). W 2016 r. liczba wniosków złożonych w Niemczech wzrosła do 722 tys., w Szwecji zaś znacząco zmalała do nieco ponad 22 tys. (Eurostat, 2016). Liczba ta do połowy października 2017 r. pozostała niemalże niezmieniona - dotychczas złożono około 20 tys. wniosków (Migrationsverket, Asylum applications). W przypadku Szwecji w okresie 2013-2015 liczba składanych wniosków azylowych stale i znacząco zwiększała się, natomiast rok 2016 okazał się przełomowy. Tak zauważalna zmiana w liczebności napływu uchodźców poszukujących azylu właśnie w Szwecji stanowi ciekawą podstawę dla analizy powiązań między kryzysem migracyjnym a zmieniającymi się preferencjami wyborczymi i poparciem społecznym dla poszczególnych partii politycznych.

Wyniki w wyborach parlamentarnych uzyskiwane przez najistotniejsze partie polityczne oraz wyniki sondaży wyborczych będą stanowiły podstawę dla przeprowadzanej analizy. Jedną z tendencji, które można zaobserwować w tym państwie w ostatnich latach, jest pewne zachwianie w stałości preferencji wyborczych. Celem artykułu jest weryfikacja hipotezy zakładającej, że zachodzi związek pomiędzy kryzysem migracyjnym, radykalizacją społeczeństwa szwedzkiego i wzrostem poparcia dla partii Szwedzkich Demokratów, jedynej w Szwecji partii o wyraźnym zabarwieniu antyimigracyjnym. W tym celu zostaną uwzględnione i poddane analizie wyniki wyborów parlamentarnych, począwszy od powstania partii Szwedzkich Demokratów, czyli od 1988 r. Wyniki wyborów parlamentarnych zostaną również skonfrontowane z liczebnością składanych w Szwecji wniosków azylowych. By dostrzec zależność między intensywnością imigracji (ale wyłącznie o charakterze uchodźczym) a wynikami wyborów, uwzględnione zostaną dane dotyczące liczby składanych wniosków azylowych z roku wyborów oraz roku je poprzedzającego. Zestawienie obu rodzajów danych pozwoli na wykazanie ewentualnej zależności między procesami migracyjnymi a preferencjami wyborczymi.

\section{Metoda}

W celu udzielenia odpowiedzi na pytanie o możliwe potencjalne związki między intensyfikującą się imigracją uchodźczą do Szwecji a preferencjami wyborczymi oraz realnymi wynikami wyborów do szwedzkiego Riskdagu, analizie poddane zostały wybrane dane o charakterze statystycznym. Jeśli wzrost poparcia dla partii antyimigracyjnej będzie czasowo zbieżny z liczniejszym napływem wniosków azylowych, wówczas zmieniające się proporcje poparcia społecznego dla poszczególnych partii mogą świadczyć o radykalizacji szwedzkiego społeczeństwa. Takie 
tendencje z kolei mogą być wynikiem wzmożonego napływu uchodźców z obszarów o znacznej odmienności kulturowej.

W związku z powyższym, przedstawione dane dotyczą po pierwsze wyników uzyskanych w wyborach parlamentarnych przez partię uznaną za prawicową i antyimigracyjną - Szwedzkich Demokratów. Obok SD, uwzględnione są również wyniki uzyskiwane przez najsilniejszą jak dotychczas szwedzką partię - Szwedzką Socjaldemokratyczną Partię Robotniczą (dalej SAP lub Socialdemokraterna). Przedział czasowy analizowanych danych obejmuje okres od powstania SD, czyli 1988 r., aż do ostatnich wyborów parlamentarnych z roku 2014.

Drugą grupą danych uwzględnionych $\mathrm{w}$ analizie jest określenie liczebności złożonych wniosków azylowych w Szwecji. W celu możliwości realnej oceny wpływu migracji na wyniki wyborów uwzględnione zostały dane pochodzące z roku poprzedzającego wybory oraz z roku, w którym wybory do Riksdagu się odbywały. Czynnik, jakim jest intensywność migracji uchodźczej, czy też imigracji w ogóle, nie jest jedynym warunkującym wynik wyborczy. Jednak analiza fluktuacji poparcia dla jedynej w Szwecji partii określanej jako prawicowa i antyimigracyjna pozwala na wysnucie konstatacji, iż liczebność imigracji, w tym przypadku uchodźczej, będzie miała znaczenie dla dyskursu prowadzonego przez taką partię oraz będzie istotnie wpływać na jej poparcie społeczne.

$\mathrm{Na}$ wynik wyborczy mogą mieć również istotny wpływ takie elementy jak sytuacja gospodarcza kraju, poziom bezrobocia czy też potencjalne kryzysy w świecie polityki. Niemniej w przypadku Szwecji zarówno sytuacja na rynku pracy. jak i kondycja gospodarki są stabilne. Szacowane bezrobocie na koniec 2017 r. w Szwecji wynosił0 7,5\%, co oznacza, że w roku tym zarejestrowano 366 tys. bezrobotnych. Jest to wynik o 6 tys. niższy w porównaniu z rokiem poprzednim (Swedish Unemployment Drops..., 2018). Zagadnienie migracji natomiast w ostatnich latach zyskało na znaczeniu, o czym świadczą m.in. wyniki badania opinii publicznej obywateli państw członkowskich Unii Europejskiej, określające postrzeganie przez nich źródeł zagrożeń. Zarówno obywatele UE ogółem, jak i sami Szwedzi na drugim miejscu wśród aktualnie najistotniejszych wyzwań dla państwa wymieniają imigrację (odpowiednio 23\% i 28\%; Eurobarometer, 2015).

Ostatnia grupa danych dotyczy badania opinii publicznej, a dokładnie poziomu poparcia dla poszczególnych partii politycznych. Badanie takie jest przeprowadzane przez Statistiska Centralbyrån dwukrotnie w ciągu roku - w maju oraz listopadzie. Określa ono rozłożenie głosów dla poszczególnych partii, gdyby wybory do Riksdagu odbywały się w dniu badania. Częściowo uwzględnione zostały tu również dane pozyskane $\mathrm{z}$ analogicznego sondażu przeprowadzanego przez YouGov, jednak mają one drugorzędne znaczenie, jego wyniki nie są bo- 
wiem dostępne dla wszystkich uwzględnionych w badaniu lat. Ponadto badanie to budzi pewne wątpliwości metodologiczne wśród badaczy. Dane zapewnione przez Statistiska Centralbyrån mają szczególnie istotne znaczenie dla przeprowadzanej analizy, ostatnie bowiem wybory parlamentarne odbyły się jeszcze przed szczytem kryzysu migracyjnego, który przypadł na 2015 r., a od 2016 r. liczba uchodźców przybywających do Szwecji zaczęła stopniowo maleć. Uwzględnienie szacowanego poparcia dla SD oraz SAP pozwala na ukazanie, w jakim stopniu zmieniało się ono w odniesieniu do zmian w liczebności składanych wniosków azylowych w szczytowym okresie kryzysu migracyjnego oraz w odniesieniu do zmieniającego się ustawodawstwa w zakresie polityki migracyjnej i azylowej w Szwecji.

Istotne $\mathrm{w}$ interpretacji uwzględnionych danych jest również umiejscowienie dwóch partii politycznych, uznanych w niniejszym badaniu za kluczowe, dla obserwacji zależności między liczebnością migracji a radykalizowaniem się społeczeństwa pod względem stosunku do obcokrajowców oraz zapewniania im opieki ze strony państwa. Socjaldemokracja może być uznana za partię proimigracyjną, podkreślającą konieczność pozostania otwartym na uchodźców i dążącą do udzielania im wsparcia. Jednocześnie SAP w okresie najliczniejszego napływu uchodźców oraz przypadków zamachów terrorystycznych w innych krajach europejskich zdecydowała się na wprowadzanie pewnych restrykcji ograniczających możliwości ubiegania się o azyl i status uchodźcy w Szwecji, zaostrzając tym samym swoje stanowisko wobec tego zagadnienia. Nie może być zatem uznana za bezwarunkowo otwartą na aspekt migracji. Z kolei SD znajduje się na przeciwległym biegunie, otwarcie opowiadając się za maksymalnym ograniczeniem liczebności imigracji oraz tworzeniem systemu wsparcia dla obcokrajowców pragnących powrócić do kraju pochodzenia.

\section{Szwedzcy Demokraci na scenie politycznej}

Partia Szwedzkich Demokratów (dalej SD) istnieje od 1988 r., jednak pierwszy sukces wyborczy osiągnęła dopiero w 2010 r. Wówczas zdołała ona przekroczyć próg wyborczy i zdobyć pierwszy raz miejsca w parlamencie - z wynikiem 5,7\% głosów w Riksdagu zasiadło 20 przedstawicieli tej partii (www.sd.se). SD określa się mianem partii konserwatywnej z elementami nacjonalistycznymi (Partileledningen vann strid..., 2011), jednak często mówi się o niej również jako o partii skrajnie prawicowej (Downs, 2012), populistycznej partii prawicowej (Rydgren, 2006) i antyimigracyjnej, czy nawet w skrajnych przypadkach neonazistowskiej (Crouch, 2014). Li Bennich-Björkman, profesor z Uniwersytetu w Uppsali, twier- 
dzi, iż rozpatrując stosunek do polityki społecznej, należałoby umiejscowić SD w centrum. Z kolei rozpatrując preferencje na linii nacjonalizm-kosmopolityzm, SD zdecydowanie znajduje się w obszarze partii skrajnie nacjonalistycznych (Roden, 2016).

Zanim SD zdołało przekroczyć próg wyborczy i wprowadzić swoich reprezentantów do Riksdagu, partia ta systematycznie budowała swoje poparcie społeczne. W roku założenia, 1988, uzyskali zaledwie 1118 głosów, w 1991 już blisko 5 tys., w 1994 r. blisko 14 tys., w 1998 r. blisko 20 tys., w 2002 r. ponad 76 tys., a w 2006 r. ponad 162 tys. głosów. W aktualnej kadencji rozpoczętej po wyborach parlamentarnych w 2014 r. stanowią trzecią siłę, zajmując 49 miejsc z uzyskanym wówczas poparciem 801178 osób, co dało im wynik 12,9\% głosów (Statistics Sweden). W grudniu 2014 r., po ostatnich wyborach i ustanowieniu nowego rządu, zawiązała się nieoficjalna koalicja wszystkich partii parlamentarnych przeciwko Szwedzkim Demokratom. Zamierzeniem było izolowanie przedstawicieli SD oraz uniemożliwienie im nadmiernego wpływu na kierunki polityki, w związku z obawą o ich radykalne poglądy wobec wyzwań migracyjnych. Rozwiązanie takie wydaje się radykalne i podważające zasady demokracji (Mirish, 2015), SD posiada bowiem znaczące poparcie społeczne, które od momentu wyborów urosło w szczycie kryzysu migracyjnego do prawie 20\% (w sondażu YouGov nawet 25\%), a parlamentarzyści z ich ramienia są reprezentantami wyborców - blisko 13\% szwedzkiego społeczeństwa. Również biorąc pod uwagę znaczenie, jakie przypisywane jest przez Szwedów zagadnieniom imigracji, izolowanie i ignorowanie poglądów SD wydaje się jednoczesnym ignorowaniem zdania przynajmniej części szwedzkich obywateli.

Obszarem, z którym najczęściej łączeni są Szwedzcy Demokraci, jest właśnie polityka migracyjna oraz ich stosunek do imigracji. Kampania wyborcza przed wyborami w 2010 r. opierała się na spocie odnoszącym się do oszczędności w budżecie państwowym, pochodzących z systemu emerytalnego. Hasłem spotu było stwierdzenie: „Możesz zdecydować, czy chcesz by zaoszczędzono pieniądze z budżetu emerytalnego, czy imigracyjnego" (tłumaczenie własne; Profile: Far-right..., 2014). Rosnące poparcie dla samej partii może zatem sugerować zwiększające się zainteresowanie samych Szwedów zagadnieniem intensywnej imigracji. We wspomnianym już badaniu przeprowadzonym przez Komisję Europejską w 2015 r. Szwedzi wśród najważniejszych wyzwań dla państwa w najbliższym czasie na drugim miejscu wymienili imigrację (28\% respondentów), a w obszarze wyzwań dla całej Unii Europejskiej na pierwszym miejscu (aż 48\% respondentów) (Eurobarometer, 2015). Może się zatem wydawać, że rosnące obawy społeczeństwa szwedzkiego wynikające $\mathrm{z}$ wzmożonych migracji $\mathrm{w}$ ostatnich latach zwiększają 
popyt na partie deklarujące w swoich programach chęć ograniczania napływu obcokrajowców. W programie partii, w odniesieniu do imigracji, znajdują się następujące postulaty:

1. Zatrzymanie masowej imigracji.

2. Skupienie się na rodzimej kulturze, zamiast wielokulturowości.

3. Ograniczenie się do systemu pracowników-specjalistów dla sektorów, w których stwierdzone są niedobory.

4. Wprowadzenie tymczasowych pozwoleń na pobyt w miejsce stałego pozwolenia na pobyt.

5. Wymóg możliwości zapewnienia utrzymania dla krewnych migrantów (korzystających z procedury łączenia rodzin).

6. Zapewnienie pomocy finansowej dla obcokrajowców decydujących się na powrót do kraju pochodzenia (www.sd.se).

Powyższe postulaty pokazują jednoznacznie negatywny stosunek partii do kwestii imigracji oraz chęć dążenia do ograniczania liczby obcokrajowców przebywających na stałe w Szwecji. Mimo wyraźnego odcinania się partii SD od neonazistowskich korzeni (Sweden Democrats leader..., 2017), słynie ona nie tylko ze swojego kontrowersyjnego programu, ale również z często publicznie wygłaszanych, budzących emocje wypowiedzi dotyczących kwestii imigracji do Szwecji. Po zamachu w redakcji Charlie Hebdo jeden z parlamentarzystów z partii Szwedzkich Demokratów zamieścił na swoim profilu na Facebooku wpis: „Pokojowa religia pokazała swoją prawdziwą twarz" (tłumaczenie własne). Jego zachowanie zostało odebrane przez szwedzkie środowiska polityczne bardzo negatywnie, łącznie ze zgłoszeniem na policję przez parlamentarzystkę z ramienia Socjaldemokracji - Veronicę Palm, doniesienia o rasowej agitacji. Wspomniany parlamentarzysta już wcześniej przyczynił się do burzliwej dyskusji na temat poprawności politycznej i zachowań dyskryminacyjnych, kiedy w grudniu 2014 r. wypowiedział się na temat mniejszości żydowskiej, której w jego odczuciu nie należy uznawać za Szwedów, dopóki „nie wyrzekną się własnej tożsamości religijnej” (Sweden Democrats defend..., 2015). Również w grudniu 2014 r. opowiadał się na łamach Dagens Nyheter za ustanowieniem wsparcia finansowego dla imigrantów, którzy wyrażają chęć powrotu do ojczystego kraju (Sweden Decrats: Pay..., 2014), co stało się jednym z oficjalnych postulatów Szwedzkich Demokratów i integralną częścią ich programu politycznego. Innym przykładem niepoprawnego politycznie działania podejmowanego przez Szwedzkich Demokratów jest również przyrównanie zagrożenia islamizmem do nazizmu. Tymczasowy lider tej partii - Mattias Karlsson ${ }^{1}$

${ }^{1}$ Lider partii w okresie od października 2014 do marca 2015. 
uznał, iż zjawisko islamizmu może być uznane nawet za większą groźbę dla państwa niż niegdyś sam nazizm, wywołując tym samym lawinową reakcję społeczności muzułmańskiej w Szwecji (Islamism Threat Greater..., 2015). Przytoczone powyżej przykłady kontrowersyjnego zachowania szwedzkiego parlamentarzysty świadczą niewątpliwie o radykalnych poglądach niektórych członków tej partii. Niemniej ich poparcie społeczne dotychczas rosło systematycznie z drobnymi wahaniami. Sami członkowie partii podejmują intensywne starania, by zerwać z próbami łączenia ich ze środowiskami neonazistowskimi, a jej aktualny lider Jimmie Åkesson jednoznacznie odcina się od takiej przeszłości partii i jej niektórych członków. Politolodzy, m.in. dr Anders Sannerstedt z Uniwersytetu w Lund, podkreślają, iż w programie partii nie ma elementów nawiązujących do wyższości rasy białej nad innymi. Zwolennicy i wyborcy SD podkreślają również, że partia ta mówi jedynie o kwestiach pomijanych przez pozostałe partie polityczne, np. liczna imigracja. SD cieszy się wysokim poparciem zwłaszcza na obszarach, gdzie społeczności obcokrajowców są liczniejsze, m.in. w okręgu Kristianstad, liczącym niecałe 80 tys. Mieszkańców, gdzie około 12 tys. jest obcego pochodzenia. Poparcie dla SD wynosiło tutaj 20\% - co piąty wyborca w wyborach 2014 r. zagłosował właśnie na Szwedzkich Demokratów (Crouch, 2014).

W sondażu poparcia dla partii politycznych zrealizowanym w czerwcu 2017 r. Szwedzcy Demokraci znaleźli się już na drugim miejscu, pokonując opozycyjną Partię Umiarkowaną. SAP uzyskała 31,1\% głosów, Szwedzcy Demokraci 18,4\%, a Partia Umiarkowana 18,1\%. Różnica jest zatem nieznaczna, jednak wskazuje na stały trend wzmacniania pozycji SD - ostatnie takie badanie przeprowadzone przez Statistiska Centralbyrån w listopadzie 2016 wskazywało na 17,5\% poparcia dla tej antyimigracyjnej partii (Anti-immigration Sweden..., 2017). W jeszcze wcześniejszym sondażu przeprowadzonym w lutym 2016 Szwedzcy Demokraci uzyskali ponad $18 \%$, co wskazuje na zachwianie tendencji wzrostowej dla tej partii. W tym samym sondażu poparcie społeczne dla SAP zanotowano na poziomie zaledwie 23,3\% - był to największy od 1967 r. kryzys poparcia dla tej partii (Sweden Social Democrat..., 2016). Począwszy od 2010 r. poparcie SD systematycznie rosło, osiągając najszybszy wzrost w okresie najliczniejszego napływu uchodźców, a zatem w okresie 2014-2015. Począwszy od 2016 r. tendencja wzrostowa uległa wyraźnemu spowolnieniu, a reakcje rządzącej koalicji w odpowiedzi na wyzwania kryzysu migracyjnego uderzyły w poparcie dla SD. W listopadowym (2017 r.) badaniu opinii publicznej Szwedzcy Demokraci uzyskali jedynie 14,8\% (The Party Preference..., 2017). Jest to znaczący spadek w stosunku do analogicznego badania z maja 2017, kiedy poparcie wynosiło jeszcze 18,4\% (Partisympatiundersökningen, 2016). 
Być może w związku ze spadkiem poparcia i wyciszeniem dyskusji na temat polityki migracyjnej w Szwecji w wyniku podjęcia przez rządzącą koalicję zdecydowanych kroków w obszarze legislacyjnym SD zaczyna poszukiwać również nowego elektoratu, nie tylko wśród rodowitych Szwedów. Podczas spotkania w Järva lider SD J. Åkesson argumentował, dlaczego również imigranci powinni głosować na partię Szwedzkich Demokratów. Jego zdaniem, imigranci nie powinni negatywnie postrzegać SD i traktować jej jako partii przeciwnej imigracji. Åkesson podkreślił bowiem, iż Szwecja ma już długą tradycję imigracji i nie należy tego zmieniać. Należy natomiast walczyć z migracjami niekontrolowanymi oraz zwłaszcza z problemami osiedli imigracyjnych - wysokim poziomem przestępczości czy ograniczeniami strukturalnymi i infrastrukturalnymi. SD dąży zatem do poprawy warunków również imigrantów i walczy o ich prawa (Sweden Democrats Leader..., 2017).

\section{Wyniki}

Poniżej w tabeli 1 przedstawione zostały dane dotyczące wyników wyborów parlamentarnych od momentu powstania partii Szwedzkich Demokratów, uwzględniające również wyniki osiągane przez SAP jako partię najpopularniejszą w Szwecji. Tabela 2 ukazuje liczebność wniosków azylowych składanych w Szwecji począwszy od 1987 r., a zatem rok przed powstaniem SD, aż do roku 2017. Ostatnia tabela (3) przedstawia wyniki badań preferencji wyborczych od 2013 r. opracowane przez Statistiska Centralbyran oraz częściowo wyniki analogicznego badania realizowanego przez YouGov.

Na podstawie danych z tabeli 1 wyraźnie dostrzegalny jest systematyczny spadek poparcia dla partii socjaldemokratycznej, której pozycja na szwedzkiej scenie politycznej była jak dotąd mocno ugruntowana. Również w ostatnich wyborach zdobyła najwyższe poparcie i w koalicji z Partią Zielonych utworzyła rząd. Z kolei poziom poparcia Szwedzkich Demokratów stopniowo rośnie, podwajając się niemalże z każdą kolejną kadencją parlamentu. Wzrost poparcia dla SD zbiega się z intensyfikacją ruchów migracyjnych, jak bowiem wynika z tabeli 2, od 2006 roku liczba składanych wniosków azylowych systematycznie wzrastała, z jedynie niewielkim zachwianiem tej tendencji w roku 2009. 
Tabela 1. Wyniki wyborów parlamentarnych w okresie 1988-2014 r. (określone w \%)

\begin{tabular}{|c|c|c|}
\hline $\begin{array}{c}\text { Rok wyborów } \\
\text { parlamentarnych/partia }\end{array}$ & $\begin{array}{c}\text { Szwedzka } \\
\text { Socjaldemokratyczna Partia } \\
\text { Robotnicza (SAP) }\end{array}$ & $\begin{array}{c}\text { Szwedzcy Demokraci } \\
\text { (Sverigedemokraterna - SD) }\end{array}$ \\
\hline 1988 & 43,2 & - \\
\hline 1991 & 37,7 & - \\
\hline 1994 & 45,3 & 0,4 \\
\hline 1998 & 36,4 & 1,4 \\
\hline 2002 & 39,9 & 2,9 \\
\hline 2006 & 35,0 & 5,7 \\
\hline 2010 & 30,7 & 12,9 \\
\hline 2014 & 31,0 & - \\
\hline
\end{tabular}

Źródło: opracowanie własne na podstawie: Historical Statistics of Elections 1910-2014, http://www. scb.se/en/finding-statistics/statistics-by-subject-area/democracy/general-elections/general-elections-results/pong/tables-and-graphs/historical-statistics-of-election-results/historical-statistics-of-elections-19102014/.

Tabela 2. Liczba wniosków azylowych złożonych w latach 1987-2017

\begin{tabular}{|c|c|c|c|}
\hline Rok & Liczebność imigracji & Rok & Liczebność imigracji \\
\hline 1987 & 18114 & 2005 & 17530 \\
\hline 1988 & 19595 & 2006 & 24322 \\
\hline 1990 & 29420 & 2009 & 24194 \\
\hline 1991 & 27351 & 2010 & 31819 \\
\hline 1993 & 37581 & 2013 & 54259 \\
\hline 1994 & 18640 & 2014 & 81301 \\
\hline 1997 & 9662 & 2015 & 162877 \\
\hline 1998 & 12844 & 2016 & 28939 \\
\hline 2001 & 23515 & 2017 & 25666 \\
\hline 2002 & 33016 & 2018 & Dane jeszcze niedostępne \\
\hline
\end{tabular}

Źródło: opracowanie własne na podstawie: Migrationsverket, Applications for Asylum Received 19841999 oraz Migrationsverket, Applications for Asylum Received 2000-2017, https://www.migrationsverket.se/download/18.2d998ffc151ac3871598175/1485556079477/Application\%20for\%20 asylum\%20received\%201984-1999.pdf; https://www.migrationsverket.se/download/18.4a5a58d51602d141cf41038/1515076827649/Application\%20for\%20asylum\%20received\%202000-2017. pdf. 
Tabela 3. Wyniki sondaży w procentach - Preferencje wyborcze, gdyby wybory odbywały się dziś

\begin{tabular}{|l|c|c|l|c|c|}
\hline \multirow{2}{*}{$\begin{array}{l}\text { Data badania } \\
\text { Statistiska Centralbyran }\end{array}$} & \multicolumn{2}{|l|}{$\begin{array}{c}\text { Wynik - sondaż } \\
\text { Statistiska } \\
\text { Centralbyrån }\end{array}$} & \multirow{2}{*}{$\begin{array}{l}\text { Data badania } \\
\text { YouGov }\end{array}$} & \multicolumn{2}{|c|}{$\begin{array}{l}\text { Wynik - sondaż } \\
\text { YouGov }\end{array}$} \\
\cline { 2 - 6 } & SD & SAP & & SD & SAP \\
\cline { 2 - 6 } Maj 2013 & 7,7 & 35,6 & Maj 2013 & Bd & Bd \\
\hline Listopad 2013 & 9,3 & 34,3 & Listopad 2013 & Bd & Bd \\
\hline Maj 2014 & 8,1 & 35,3 & Maj 2014 & Bd & Bd \\
\hline Listopad 2014 & 12,4 & 32,2 & Listopad 2014 & Bd & Bd \\
\hline Maj 2015 & 14,4 & 30,0 & Maj 2015 & Bd & Bd \\
\hline Listopad 2015 & 19,9 & 27,6 & Listopad 2015 & Bd & Bd \\
\hline Maj 2016 & 17,3 & 29,5 & Maj 2016 & 23,0 & 23,0 \\
\hline Listopad 2016 & 17,5 & 29,2 & Listopad 2016 & 25,0 & 22,0 \\
\hline Maj 2017 & 18,4 & 31,1 & Maj 2017 & 17,0 & 24,0 \\
\hline Listopad 2017 & 11,9 & 33,6 & Listopad 2017 & 20,7 & 25,2 \\
\hline
\end{tabular}

Źródło: opracowanie własne na podstawie: Statistiska Centrabyran (2016) oraz YouGov Sweden.

Z badania preferencji wyborczych Szwedów, przeprowadzanego dwukrotnie w ciągu roku (w maju i listopadzie) przez Statistiska Centralbyrån, wynika, że gdyby wybory parlamentarne odbywały się w dniu sondażu, SD uzyskałaby największą liczbę głosów w listopadzie 2015 r. - blisko 20\%. W tym samym badaniu SAP uzyskała najniższe poparcie spośród wszystkich realizowanych sondaży w okresie od maja 2013 r. do listopada 2017 r.

\section{Wnioski}

Przeprowadzona analiza wyselekcjonowanych danych pozwoliła na zaobserwowanie wzrostu popularności wśród wyborców Szwedzkich Demokratów - partii określonej mianem antyimigracyjnej - w ostatnich latach. Najwyższe poparcie zgodnie z sondażami przeprowadzanymi systematycznie przez Statistiska Centralbyrån zbiegło się czasowo z okresami najliczniejszego napływu wniosków azylowych w 2015 r. było to ponad 160 tys. wniosków. Poparcie dla SD w tym czasie określano na poziomie $19,9 \%$. W roku kolejnym wraz ze spadkiem liczby wniosków azylowych malało również poparcie społeczne dla SD - do 17,5\% w listopadzie 2016. Według danych analogicznego sondażu YouGov w listopadzie 2016 r. chęć głoso- 
wania na SD deklarowała nawet jeszcze większa część społeczeństwa, bowiem aż 25\% Szwedów, sondaż ten jednak jest krytykowany ze względu na stosowaną metodologię (New Poll Shows..., 2015). Jednocześnie wzrastało poparcie dla SAP z 27,6\% pod koniec 2015 r. do 29,2\% w listopadzie 2016 i do 33,6\% w listopadzie 2017. Takie odwrócenie wcześniejszych tendencji wzrostowych w przypadku SD i spadkowych w przypadku SAP może być spowodowane zmianą dotychczasowej, niezwykle otwartej polityki socjaldemokratów względem uchodźców.

Wykres 1. Poparcie dla SD w okresie 1998-2017 oraz liczba wniosków azylowych złożonych w latach 1998-2017

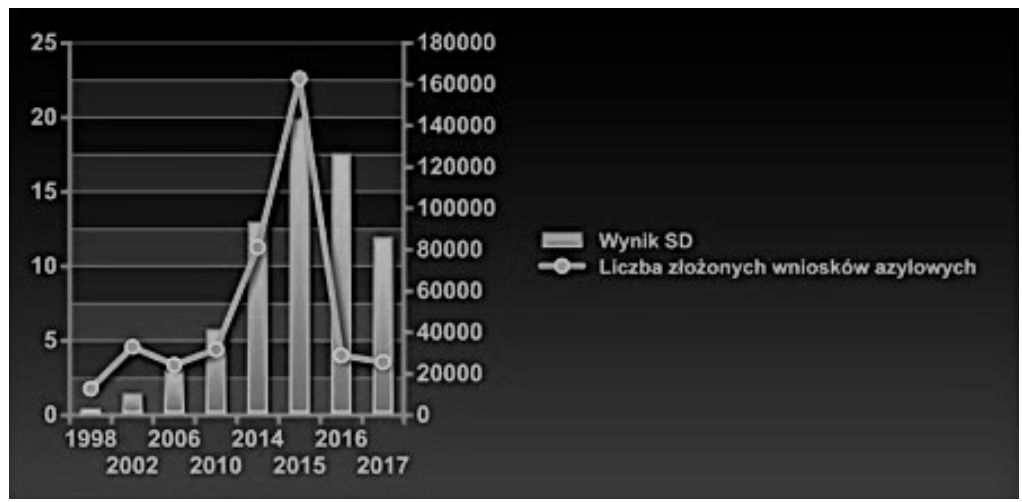

Źródło: opracowanie własne.

W czerwcu 2016 r. Riksdag ustanowił tymczasowe prawo ograniczające możliwość uzyskania pozwolenia na pobyt dla uchodźców i członków ich rodzin, które ma obowiązywać przez okres trzech lat. Dotychczas osoby będące uchodźcą bądź uprawnione do uzyskania ochrony uzupełniającej uzyskiwały automatycznie po pozytywnym rozpatrzeniu wniosku pozwolenie na pobyt stały. Aktualnie mogą uzyskać jedynie pozwolenie na pobyt tymczasowy - na trzy lata w przypadku uchodźców oraz trzynaście miesięcy dla osób uprawnionych do ochrony uzupełniającej. Ograniczone zostały również możliwości skorzystania z procedury łączenia rodzin w przypadku osób, które złożyły swoje wnioski azylowe już po 24 listopada 2015 r. (Limited Possibilities of..., 2016). Powyższe zmiany legislacyjne niewątpliwie wskazują na pewną radykalizację dotychczas otwartych na imigrantów i uchodźców Szwedów, zarówno samego społeczeństwa, jak i rządzących elit. Szwedzka Socjaldemokratyczna Partia Robotnicza, stojąca dotychczas na straży szwedzkiej tolerancji i otwartości, sama zdecydowała się na podjęcie stosownych kroków wobec nowych wyzwań wynikających z kryzysu migracyjnego. Mogło to 
również w bezpośredni sposób przełożyć się na poparcie społeczne dla SAP, która w 2017 r. ponownie zdołała przekroczyć 30\% poparcia.

Kolejnym przykładem na zmianę postaw wśród czołowych polityków jest również wypowiedź minister finansów Magdaleny Andersson, która w wywiadzie dla Dagens Nyheter w grudniu 2017 r. przyznała, iż system integracyjny w Szwecji nie funkcjonuje tak jak powinien, a przyjęcie tak znaczącej liczby uchodźców było błędną decyzją. Szwecja nie może decydować się na otwieranie swoich granic dla tak wielu obcokrajowców właśnie w związku z trudnościami integracyjnymi. Brak reakcji rządu i dalsze nieograniczanie napływu obcokrajowców mogłoby oznaczać dla szwedzkiego społeczeństwa trudności (Integrationer fungerar inte..., 2017). Aktualne szacowane poparcie dla SAP wynosi już niemalże 34\% przy jednoczesnym bardzo znaczącym spadku poparcia dla SD (jedynie 11\%). Wnioskować można zatem, że reakcja socjaldemokratów i podjęte kroki zmierzająca do ograniczania negatywnych skutków kryzysu migracyjnego przynoszą efekt. Wskazuje to również na znaczenie, jakie wyborcy szwedzcy przywiązują do polityki partii politycznych wobec migracji. Jednocześnie trudno jednoznacznie ocenić stopień radykalizacji szwedzkich wyborców, biorąc pod uwagę ponowne zwrócenie się w kierunku socjaldemokratów, których stanowisko w kwestii migracji wprawdzie uległo zaostrzeniu, ale jednak ich stosunek do obcokrajowców jest zdecydowanie bardziej umiarkowany w porównaniu do negatywnie nastawionych wobec intensywnego napływu imigrantów Szwedzkich Demokratów. Dodatkowo, przywołany już sondaż przeprowadzany przez YouGov wskazuje na podobne tendencje, choć o mniejszej intensywności. Wyjątkiem był sondaż z listopada 2016, kiedy to Szwedzcy Demokraci byli liderem, a ich poparcie było nawet wyższe od tego deklarowanego dla SAP. Stosunek ten wynosił $25 \%$ do $22 \%$ (w tym samym okresie w sondażu Statistiska Centralbyrån poparcie to wynosiło 17,5\% dla SD do 29,2\% dla SAP). Począwszy od 2017 r., tendencja ta jednak odwróciła się i podobnie jak w przypadku badań Statistiska Centralbyrån, to SAP uzyskuje wyższe poparcie. Sondaż ten może zatem również potwierdzać, iż zmiana stanowiska socjaldemokratów oraz ograniczenie napływu uchodźców złagodziło radykalizowanie się elektoratu szwedzkiego. Wydawać może się zatem, iż w Szwecji w wyniku kryzysu migracyjnego faktycznie dało się zaobserwować znaczne zmiany w postawach wyborczych, które zbieżne były z okresami najliczniejszego napływu obcokrajowców. Kryzys migracyjny wpłynął również na zaostrzenie się samego dyskursu politycznego i podjęcie kroków ze strony partii dotychczas przychylnej migracji, zmierzających do ograniczania liczby imigrantów. Jednocześnie, wraz z podjęciem podstawowych zmian w zakresie legislacji dotykającej zagadnień migracyjnych, tendencje radykalizacji poglądów politycznych Szwedów i ich preferencji wybor- 
czych uległy osłabieniu. SAP ponownie zyskuje na popularności, SD zaś została zepchnięta na dalszy plan, choć sam aspekt migracji nadal pozostaje obecny w aktualnej debacie politycznej.

\section{Bibliografia:}

BBC News. (2014). Profile: Far-right Sweden Democrats. Pobrane z: http://www.bbc.com/ news/world-europe-29202793.

Crouch, D. (2014). The Rise of the Anti-Immigrant Sweden Democrats: "We don't Feel at Home Any More, and it's Their Fault." The Guardian. Pobrane z: https://www.theguardian.com/world/2014/dec/14/sweden-democrats-flex-muscles-anti-immigrantkristianstad.

Dagens Nyheter. (2017). Integrationen fungerar inte som den ska. Pobrane z: https://www. dn.se/nyheter/politik/integrationen-fungerar-inte-som-den-ska/.

Downs, W.M. (2012). Political Extremism in Democracies: Combating Intolerance. Basingstoke: Palgrave Macmillan.

European Comission - Eurobarometer. (2015). Life in the European Union. Pobrane z: http:// ec.europa.eu/commfrontoffice/publicopinion/archives/eb/eb83/eb83_fact_se_en.pdf.

Eurostat. (2015). Asylum Statistics. Pobrane z: http://ec.europa.eu/eurostat/statistics-explained/index.php/Asylum_statistics.

Eurostat. (2016). Asylum Statistics. Five Main Citizenships of (non-EU) Asylum Applicants, 2016 (Number of First Time Applicants, Rounded Figures). Pobrane z: http://ec.europa.eu/eurostat/statistics-explained/index.php/File:Five_main_citizenships_of_(non-EU)_asylum_applicants,_2016_(number_of_first_time_applicants,_rounded_figures)_YB17.png.

Migrationsverket. (2015). Asylum Applications 2015. Pobrane z: http://www.migrationsverket.se/English/About-the-Migration-Agency/Facts-and-statistics-/Statistics.html.

Migrationsverket. (2016). Limited Possibilities of Being Granted a Residence Permit in Sweden. Pobrane z: https://www.migrationsverket.se/English/About-the-Migration-Agency/Legislative-changes-2016/Limited-possibilities-of-being-granted-a-residencepermit-in-Sweden.html.

Mirish, J. (2015). The Sweden Democrats: How to Deal with a One-Issue Party. Huffington Post. Pobrane z: https://www.huffingtonpost.com/john-mirisch/the-sweden-democrats-how_b_8068416.html.

Roden, L. (2016). Just How "Far Right" are the Sweden Democrats? The Local. Pobrane z: https://www.thelocal.se/20161010/just-how-far-right-are-the-sweden-democrats.

Rydgren, J. (2006). From Tax Populism to Ethnic Nationalism: Radical Right-wing Populism in Sweden. Stockholm: Berghahn Books.

Statistics Sweden. (2014). Historical Statistics of Elections 1910-2014. Pobrane z: http:// www.scb.se/en/finding-statistics/statistics-by-subject-area/democracy/general-elections/general-elections-results/pong/tables-and-graphs/historical-statistics-of-election-results/historical-statistics-of-elections-19102014/. 
Statistics Sweden. (2016). Partisympatiundersökningen (PSU). Pobrane z: http://www.scb. se/Statistik/_Publikationer/ME0201_2016M11_BR_ME60BR1602.pdf.

Statistics Sweden. (2017). The Party Preference Survey: "If there were an election to the Riksdag today”. Pobrane z: http://www.scb.se/en/finding-statistics/statistics-by-subject-area/ democracy/political-party-preferences/party-preference-survey-psu/pong/tables-and-graphs/party-preferences-psu/the-party-preference-survey-if-there-were-an-electionto-the-riksdag-today/.

Statistiska Centrabyran, Partisympatiundersökningen. (november 2016). Pobrane z: http:// www.scb.se/Statistik/_Publikationer/ME0201_2016M11_BR_ME60BR1602.pdf.

Svenska Dagbladet. (2011). Partiledningen vann strid om principprogrammet. Pobrane z: https:/www.svd.se/partiledningen-vann-strid-om-principprogrammet.

Sverige Radio. (2015). New Poll Shows Record Support for the Sweden Democrats. Pobrane z: http://sverigesradio.se/sida/artikel.aspx?programid=2054\&artikel=6238243.

The Local. (2014). Sweden Democrat: Pay Migrants to Leave. Pobrane z: http://www. thelocal.se/20141214/sweden-democrat-pay-migrants-to-leave.

The Local. (2015). Islamism Threatgreater than Nazism: SD Leader. Pobrane z: http:// www.thelocal.se/20150127/sweden-democrat-compares-islam-threat-to-nazism.

The Local. (2015). Sweden Democrats Defend Islam Comment. Pobrane z: http://www. thelocal.se/20150109/sweden-democrat-rapped-for-paris-comments.

The Local. (2016). Sweden's Social Democrat Party Hits Record Low in Poll. Pobrane z: http://www.thelocal.se/20160124/swedens-social-democrats-hit-record-low-in-poll.

The Local. (2017). Anti-Immigration Sweden Democrats Overtake Moderates as Sweden's Second-Largest Party: Poll. Pobrane z: https://www.thelocal.se/20170601/anti-immigration-sweden-democrats-overtake-moderates-as-swedens-second-largest-partypoll.

The Local. (2017). Sweden Democrats Leader Åkesson: “I Support Immigration”. Pobrane z: https://www.thelocal.se/20170618/sweden-democrats-leader-kesson-i-support-immigration.

The Local. (2018). Swedish Unemployment Drops in 2017. Pobrane z: https://www.thelocal.se/20180111/swedish-unemployment-drops-in-2017.

Vart partii. (2019). Pobrane z: https://sd.se/vart-parti/.

YouGov Sweden. Pobrane z: https://yougov.se/news/2017/11/23/sverigedemokraternabackar-i-opinionen/. 